\title{
Interior Reconciliation: Adopting a Posture of Peace
}

\author{
Kieran Campbell \\ Boston College School of Theology and Ministry (Brighton, MA)
}

\begin{abstract}
Peacemaking is always complex. Too often this complexity proves so burdensome that those involved find themselves paralyzed, unable to locate an appropriate starting point for the process of reconciliation. This essay proposes that "interior reconciliation" in which individuals address and engage the interior dissonances that expose them as both sinful and graced - provides a helpful first step in the process of "exterior reconciliation" between individuals, communities, and nations. Efforts of reconciliation, which are in every case complicated, remain unsustainable if the individuals involved are not able to reconcile themselves with themselves as such. I suggest three important movements - declaration (acknowledging sinfulness and gracefulness as realities of the human experience), detection (continually locating the presence of sin and grace), and disposal (surrendering sinfulness and offering gracefulness to God) — which, in the company of the Spirit, provide what I hope will be a useful and realistic framework for the journey of interior reconciliation.
\end{abstract}

\section{Text}

The complexity of peacemaking cannot be understated. ${ }^{1}$ Too often this complexity proves so burdensome that those involved find themselves paralyzed, unable to locate an appropriate starting point for the process of reconciliation. These frustrations frequently bring the process to a grinding halt. We must not gloss over these intricacies, for a feigned simplification of conflict rarely yields peace. Perhaps, however, a more fruitful starting point lies in assuming a posture of "interior reconciliation" in which individuals address and engage their interior dissonances, exposing themselves as both sinful and graceful. This coming to terms with our reality has the potential to cultivate reconciliation and peace that is sustainable and enduring. Ultimately, by reconciling our interiority with the human realities of

${ }^{1}$ While recognizing the distinction between peacemaking as a political and legislative process realized via diplomatic negotiations and peacebuilding as a process of reconciliation between individuals "on the ground," I will use the word "peacemaking" broadly to refer to the process of "making peace." Because the term will not be used technically and will only be used to address vague generalities, I find this usage appropriate in this essay. 
grace and sin, we allow ourselves to be transformed and thus, enable ourselves to be transformative in efforts of "exterior reconciliation.".

I suggest three internal postures-declaration, detection, and disposalwhich, in the company of the Spirit, provide what I hope will be a useful and realistic framework for the journey toward interior reconciliation. I hope not to diminish the critical role of current peacemaking efforts, but instead to acknowledge that self-reconciliation ought not be undermined or overshadowed by global, national, or interpersonal peacemaking efforts, which often seize the majority of peacemakers' attention. These suggestions are not new or unfamiliar; perhaps what is novel, however, is the willingness to assimilate them into one's interiority before expecting others to do the same. My hope is that our lives might be saturated in peace; that you and I might be deeply satisfied with who we are; that the light of the life of peace might shine before others that they might glorify our Father in heaven (Matthew 5:16).

The dissonances that necessitate interior reconciliation, though unique to the individual, are inseparable from the human experience. In his letter to the Romans, Paul observes: "I do not understand my own actions. For I do not do what I want, but I do the very thing I hate" (7:15). This statement pointedly exposes the disharmony implicit in the human experience. I need not belabor this point. We are all too familiar with the guilt that accompanies an action that we know we ought not have taken, or an inaction that we know we ought to have pursued. Sin has been conceptualized in myriad ways: as concupiscence, the disorder of desire, the movement of the will away from God, a "missing of the mark" or a "wandering from the way." We are not here concerned with the nature of sin and sinfulness but with the fact that it is present in our experience. ${ }^{3} \mathrm{We}$ are not strangers to internal disharmony; it lies at the core of our many hostilities, and perhaps, connects us most profoundly. Our experience with dissonance, and our desire to be free from it, is perhaps what draws us most eagerly to "the peace of God, which surpasses all understanding" (Philippians 4:7).

2 The term "exterior reconciliation" will be used broadly and vaguely as the antithesis of "interior reconciliation" insofar as interior reconciliation refers to an individual's confrontation with his or her interior dissonances while exterior reconciliation refers to a coming to terms with the dissonances occurring outside of the individual whether global, national, intercommunal, or interpersonal.

${ }^{3}$ Though we will not here entertain the nature of sin, many have and will continue to do so. Augustine and Aquinas are two, among many, to whom the tradition looks for an extensive treatment of sin and sinfulness. For introductory remarks see William E. Mann, "Augustine on Evil and Original Sin" in The Cambridge Companion to Augustine, eds. Eleonore Stump and Norman Kretzmann, (Cambridge: Cambridge University Press, 2001), 40-48. For Aquinas' extensive treatment of sin see Summa Theologica, Ia-IIae, qq. 71-89. For an introduction to Aquinas' ethics, including the role of the will in sin see: Ralph McInerny, "Ethics" in The Cambridge Companion to Aquinas, eds. Norman Kretzmann and Eleonore Stump, (Cambridge: Cambridge University Press, 1993), 196-216. 
Before exploring the process of interior reconciliation and its role in larger peacemaking efforts it proves helpful to examine what interior reconciliation is not. It is not "self-absolution," in which individuals claim the ability to forgive themselves for sins that they have committed. Forgiveness can only be offered by the one who has been offended. Ultimately, however, the gift of forgiveness is the gift of God to both the Forgiver and the Forgiven, made possible only by the gift of divine grace. Accordingly, interior reconciliation is not a denial of the realities of human sinfulness or gracefulness. Instead, it necessitates a more intimate familiarity with these realities and their presence in our daily lives. I seek not to deny or even distract from the social reality of both sin and reconciliation. Instead, by developing a process of interior reconciliation, I hope that social sin may be more deeply acknowledged and social reconciliation more profoundly experienced. Finally, I suggest neither complacency in sin — a comfortability in our sinfulness that prevents us from striving for freedom in Christ - nor an unrealistic quest for personal perfection that is divorced from our salvation in Christ. Having recognized these boundaries, we can proceed confidently in our exploration of interior reconciliation.

The language of "posture" is intentional. Assuming a particular posture, whether internal or somatic, involves three movements that operate cyclically. First, we adopt a posture that is both contextually appropriate and reasonably comfortable. Immediately after assuming a posture we begin to settle into our new stance. Shoulders begin to slump, legs cross, toes tap. No matter how much settling in we do, we continually adjust and readjust. Our posture is continually modified, our body constantly making minute changes to prevent us from toppling over. Nevertheless, at some point, though still wavering, we consider ourselves to be "balanced." Eventually, after losing our balance or becoming stiff from maintaining it, we return to the first movement and reinvigorate the cycle. Ideally, with practice and intentionality, the interior postures suggested below, participate in a similar cycle in which they become no longer intentional movements but rather become subconsciously and routinely present, inseparable from our very disposition. These postures provide a balanced stance that can better withstand the collision of grace and sin. We ultimately strive to ground ourselves that we might better ground others who are struggling to reconcile. Having recognized posture as cyclical and routine, let us now consider what a posture of interior reconciliation might look like in lived experience. 
The first of the three postures is one of declaration. This initial step, as in all instances of reconciliation, requires an openness in which reality can be recognized and addressed as it is. One might declare, like Luther, "I am a sinner and I am full of grace," or "I am both sinful and saved." This declaration requires the understanding that my sinfulness is inseparable from $m y$ decision-making and that my gracefulness is inseparable from God's gratuitous gift. I am sinful because I have chosen sin. I am graced, not primarily because I have chosen it, but because God has first offered it. By acknowledging the tension woven into our humanity, our aim here is not to relieve it, but to expose the tension as such, that it might not remain foreign.

Recognition of this disharmony provides the necessary space for our second movement: detection. A posture of detection invites the graced sinner to locate grace and sin within his or her lived experience. Though they do not define us, we are invited to recognize instances of temptation and sin as well as patterns of sinfulness that have shaped our relationship with God, others, and ourselves. Likewise, we are invited to acknowledge particular moments of grace, the cradle of the divine. Patterns of grace may also be identified: a budding friendship, a fruitful prayer practice, a broken relationship in the process of healing. The Ignatian Examen provides a fruitful venue in which this detection might occur. The Examen challenges its practitioners to become cognizant of God's revelation in their life as well as the ways in which they have or have not been present to God. ${ }^{5}$ This detection requires awareness and acuity; it is active, always seeking.

Our efforts to detect both sin and grace must remain balanced. It is important that we not get too caught up in our sinfulness and equally important that we not neglect its presence. Additionally, we must be wary of the temptation to

${ }^{4}$ This declaration is reminiscent of Luther's proclamation, "simul justus et peccator" (at once righteous and sinner). Romans 7 exposes these tensions, serving as the Scriptural foundation for our declaration. Notably, this claim is separate from that of justification by faith alone.

${ }^{5}$ Timothy Gallagher provides a beautifully accessible introduction to the Examen in his The Examen Prayer: Ignatian Wisdom for Our Lives Today (New York: Crossroad, 2006). I think my suggestions regarding interior reconciliation differ from the Examen in three small but significant ways: 1.) While the Examen functions within a particular spiritual framework (Ignatian, Catholic, Christian), the process of interior reconciliation is perhaps more accessible to those both within and without a religious/spiritual tradition; 2.) We must, in the process of interior reconciliation, explicitly declare our tension and dissonance. Though this is perhaps implicit to the Examen, it is important to make our declaration explicit and impossible not to confront. 3.) Interior reconciliation is necessarily forward-looking. We adopt this posture of peace for our own gain and that others might achieve peace through us. This too is perhaps implicit with the Examen and with the Jesuit charism; however, it is once again made explicit in this process. My suggestion most differs from the Examen or an examination of conscience because it is necessarily oriented to the reconciliation of the Self that the Self might be more effectively reconciled with the Other-it is fundamentally social. What I suggest is not an instance of reflection, but the adoption of a disposition, not a moment of consideration but an internalization that ought to be constantly assimilated for the sake of a larger peace. 
cordon off particular areas of our life. All of life's facets must be exposed and examined for the presence of both grace and sin: our habits, our assumptions, our sexuality, our language, our thoughts. All must be laid bare before ourselves and before God in order for us to take an accurate inventory of the presence of grace and sin.

The third and final movement in our quest for interior harmony is that of disposal. Having recognized the tension between our sinfulness and gracefulness and after acknowledging the presence of each in our lived reality, we are invited to dispose of both as is appropriate. The verb "dispose" serves us well insofar as it has two connotations that prompt fruitful and complementary reflection. We are first invited to "throw away" our sinfulness. Most explicitly, within the Catholic tradition, this disposal occurs in the sacrament of reconciliation. Internally, the sacrament requires that we cast off even our inclination to sin, surrendering our propensity to sin as an offering to our God who is Love. Accepting grace, we reaffirm our efforts to sin no more and to avoid the near occasion of $\sin .{ }^{6}$ We assume a posture of receptivity and openness to the grace of God.

By disposing, and indeed dispossessing, our sinfulness, we enable ourselves to be more fully disposed to grace, more open to the movement of God the giver of all grace. We are invited to reflect this grace back to God in our resting and our rising, our prayer and our song, our private and public worship, that we might go forth in peace, glorifying the Lord by our lives. ${ }^{7}$ This act of disposal, instead of suggesting a dispassionate forgetfulness, insists that we remember the moments of grace and sin which we offer, that they might inform our going forth.

Having briefly explored the postures of declaration, detection, and disposal it is prudent to reflect on the implications of internal reconciliation in the exterior. By adopting these postures of peace we allow ourselves to be transformed. Ultimately, we open ourselves to the movement of the Spirit, which, as Paul suggests in his second letter to the Corinthians, is always transformative: "And all of us...seeing the glory of the Lord as though reflected in a mirror, are being transformed into the same image from one degree of glory to another; for this comes from the Lord, the Spirit" (3:18). Two chapters later Paul once again recognizes the inevitability

\footnotetext{
${ }^{6}$ This wording comes from a popular act of contrition used by many Catholics in the sacrament of reconciliation. The prayer is as follows: $O$ my God, I am heartily sorry for having offended you, and I detest all my sins, because of Your just punishments, but most of all because they offend You, my God, who are all-good and deserving of all my love. I firmly resolve, with the help of Your grace, to sin no more and to avoid the near occasion of sin. Amen.

${ }^{7}$ The imperative to go forth in peace comes from the Concluding Rite of the Catholic Mass. See the English Translation of The Roman Missal, 2010.
} 
of this transformation: "So if anyone is in Christ, there is a new creation: everything old has passed away; see, everything has become new!" (5:17). When we invite the Spirit, or when we place ourselves in a position to respond to the invitation of the Spirit that already awaits us, we are bound to be transformed.

The nature of this transformation will not be in every case identical. However, trusting in our desire to seek peace, we proceed in the confidence that peace, in some capacity, will be experienced. This transformation bears its greatest fruit when we find ourselves able to recognize that the tensions within us exist also in others. These tensions, when ignored, interfere with reconciliation; however, when acknowledged, they provide a locus of profound solidarity. We are drawn into ourselves not that we might stay there, but that we might better offer our gift of peace to others. Our transformed disposition enables us to approach larger efforts of reconciliation with the same sacrificial mindset. We willfully transform ourselves in order to assist in the transformation of others. We seek peace within ourselves in order to promote peace in others. Our dissonance is resolved into interior harmony such that we can better achieve resonance with others. As God has offered God's gift of peace to us, so too might we offer our newfound peace to our brothers and sisters. Our quest for peace must be socially oriented.

By no means have I outlined a tried and true method of making peace. I have not provided any empirical data to support my claims. I have not even given any concrete examples with which to work. In doing so, I have achieved my goal: to present my reflections of the potential fruits of addressing our interiority as it is; to prompt reflections on the importance of interior disposition; to propose some practical exercises that may be of use; and as a reminder that reconciliation starts not from without but from within. May we never forget our role in making peace.

\section{Bibliography}

Aquinas, Thomas. Summa Theologica. Complete English Edition in Five Volumes. Translated by Fathers of the English Dominican Province. Westminster, MD: Christian Classics, 1981.

Gallagher, Timothy M. The Examen Prayer: Ignatian Wisdom for Our Lives Today. New York: Crossroad, 2006.

Mann, William E. “Augustine on Evil and Original Sin.” In The Cambridge Companion to Augustine, edited by Eleonore Stump and Norman Kretzmann, 40-48. Cambridge Companions to Philosophy. Cambridge: Cambridge University Press, 2001. 


\section{CAMPBELL: INTERIOR RECONCILIATION}

Mclnerny, Ralph. "Ethics.” In The Cambridge Companion to Aquinas, edited by Norman Kretzmann and Eleonore Stump, 196-216. Cambridge Companions to Philosophy. Cambridge: Cambridge University Press, 1993. 